\title{
The renin-angiotensin system and coronary vasomotion
}

\author{
G Ertl, K Hu, W R Bauer, B Bauer
}

II Medizinische Klinik, Klinikum Mannheim, Universität

Heidelberg,

Mannheim, Germany

G Ertl

$\mathrm{K} \mathrm{Hu}$

W R Bauer

B Bauer

Correspondence to:

Prof Dr G Ertl, II

Medizinische Klinik,

Universität Heidelberg,

PO Box 68135, Mannheim, Germany.
Klinikum Mannheim,

Coronary vasomotion, which controls myocardial perfusion, is closely regulated by myocardial metabolic demand and has been assessed by changes of coronary vascular resistance. Only two decades ago evidence of neural and hormonal control overriding the metabolic control of coronary arterioles, which represent the "resistance vessels" was reported (fig 1). Numerous groups reported persistence of a coronary vasodilator reserve or progressive vasoconstriction despite ischaemia. ${ }^{1-11}$ Studies showed that $\alpha$ adrenergic receptor mediated coronary constriction may restrict metabolic dilatation to avoid wasting blood flow to the heart muscle. ${ }^{12}$ Infusion of $\alpha$ receptor stimulating or blocking drugs, and activation of the sympathetic nervous system during $\beta$ blockade, defined the potential of such influences on coronary blood flow. ${ }^{1314} \alpha$ Receptor coronary constriction may be one component of the constrictor tone during ischaemia. ${ }^{14-18}$ In the meantime, numerous mediators have been identified which may constrict or dilate coronary vessels. Thus receptors are abundant in coronary vas-

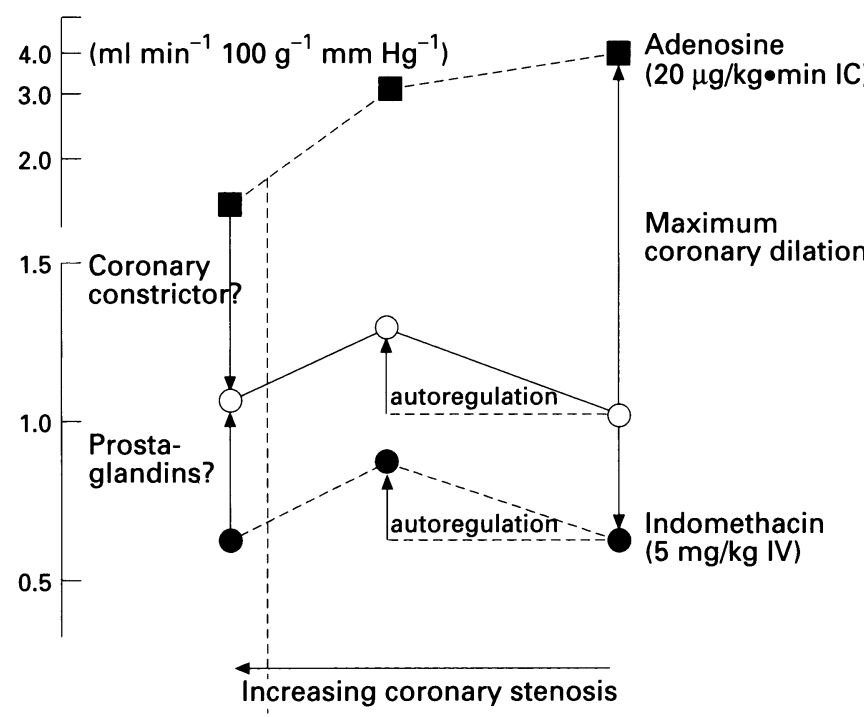

Figure 1 Effect of lowering perfusion pressure of a cannulated coronary artery (from right to left) in analogy to progressive coronary stenosis on coronary conductance as determined distal to "coronary stenosis". Solid line represents control situation with an initial autoregulatory increase in coronary conductance (coronary vasodilatation). Further lowering of coronary perfusion pressure to induce myocardial ischaemia left of broken vertical line), as indicated by lactate production and depression of myocardial function, results in a decrease rather than a further increase in coronary conductance, indicating results in a decrease rather than a further increase in coronary conductance, indicating
exhaustion of coronary autoregulation. Intracoronary infusion of adenosine increases coronary conductance, suggesting a vasodilator reserve or a constrictive tone despite myocardial ischaemia. The cyclo-oxygenase inhibitor indomethacin reduces coronary conductance, suggesting a vasodilator tone of cyclo-oxygenase products of arachidonic acid in this model of myocardial ischaemia. (Ertl $G$. Effect of angiotensin-converting enzyme inhibitors on myocardial perfusion. In: Schultheiss HP, ed. New concepts of viral heart disease. Berlin: Springer Verlag, 1988:454-64.) culature for various mediators, and the physiological significance of such mediators remains obscure.

Vasomotion of large conductance vessels does not normally contribute to regulation of coronary blood flow. However, in the presence of atherosclerotic lesions, coronary thrombosis, and spasm, large vessels limit myocardial perfusion and induce ischaemia, angina pectoris, and infarction. Abnormal vasomotion of large coronary vessels has been appreciated in the last decades, when coronary angiography became available during acute coronary syndromes. Atherosclerotic vessels seem to respond with vasoconstriction in situations where vasodilatation should be required. The endothelium and mediators released by the endothelium play a critical role in mediating vasomotion in normal and diseased large and small coronary vessels. However, multiple potential mediators confuse our understanding of coronary vasomotion.

Previously, agonists and antagonists of various mediator systems have been used to identify a potential role for coronary vasomotion. Effects of agonists are dose dependent, and it remains unclear from most studies which concentrations of agonists may occur under physiological or pathophysiological conditions. The use of antagonists might increase our understanding, but the specificity of available inhibitors is limited. In addition, the effect of mediators is balanced by other mediators, and blockade of one may activate others. For the coronary circulation, the situation is even more complicated since coronary blood flow is under the influence of aortic pressure, compressive forces of the ventricle, and myocardial metabolic demand. Thus interventions in the coronary circulation with any agonist or antagonist result in complex changes which are difficult to analyse. Response to mediators may be different in various sections of coronary circulation, ${ }^{19}$ and diseases which alter vasomotion may affect large and small vessels differently. Finally, acute effects of an agonist or antagonist may be different from chronic effects. Changes of coronary vascular muscle tone are responsible for acute coronary vasomotion, but coronary vasomotion may well be influenced by chronic morphological changes of the coronary vessel wall and perivascular tissue.

\section{Importance of the renin-angiotensin system for instantaneous regulation of coronary vascular tone}

Two components of the renin-angiotensin system are now generally recognised: a systemic 
circulating, and a local renin-angiotensin system. The systemic system controls acute changes of vascular tone and aldosterone release from the adrenals. The local system may control chronic adaptation of the vasculature and perivascular tissue, the growth of smooth muscle cells, cardiac myocytes and fibroblasts, and accumulation of connective tissue. The active moiety of the system controlling coronary vasomotion is angiotensin II. Angiotensin II is liberated by the carboxypeptidase angiotensin converting enzyme (ACE) from the peptide angiotensin I. Angiotensin I is cleaved from the protein angiotensinogen by the proteinase renin. Infusion of angiotensin I to isolated heart preparations results in coronary vasoconstriction, indicated by a dose dependent reduction of coronary blood flow. ${ }^{20-22}$ Angiotensin II exerts a direct coronary vasoconstrictor effect in humans..$^{23}{ }^{24}$ This proves the existence of ACE and angiotensin II receptors in the coronary vascular system. The relation of blood flow reduction by angiotensin I to blood flow reduction by angiotensin II may be used to calculate the conversion of angiotensin I to angiotensin II, which has been found to be $10-100 \%$ in different models under various conditions. ${ }^{20-22}$ Immunohistology and in vitro hybridisation studies suggest that in the heart ACE is present in the endocardium, epicardial coronary vessels, and in the myocardium. ${ }^{25} 26$ Conversion of angiotensin I to angiotensin II is regulated under pathophysiological conditions.

\section{Effects of inhibitors of the renin-} angiotensin system on coronary vessels ACE inhibitors and angiotensin II receptor antagonists have no effect on coronary blood flow in preparations without activation of the renin-angiotensin system ${ }^{27} 28$ and in patients without heart disease. However, in the latter, the ACE inhibitor teprotide dramatically increased coronary blood flow in three patients with high plasma renin, suggesting a renin dependent coronary effect of teprotide. This effect was also reflected by a good correlation between plasma renin activity and changes of coronary flow after teprotide. ${ }^{29}$ These data suggest that under normal physiological conditions, angiotensin II does not control coronary blood flow. In contrast, studies which focused on vasomotion of large coronary vessels found vasodilator effects of ACE inhibitors in dogs. ${ }^{30}$ In anaesthetised dogs, an angiotensin II type 1

Comparison of angiotensin I/II (ANG I, II) effects in controls, during hypoxia and ischaemia. All the values are expressed as means (SEM)

\begin{tabular}{|c|c|c|c|c|}
\hline & $\begin{array}{l}E D_{\text {SaANG I }} \\
(p m o l)\end{array}$ & $\begin{array}{l}E D_{\text {SoANG II }} \\
(p m o l)\end{array}$ & $\begin{array}{l}E D_{\text {SOANGI }} I \\
E D_{\text {SOANG II }}\end{array}$ & $\begin{array}{l}\text { Conversion } \\
\text { of } A N G I(\%) \dagger\end{array}$ \\
\hline $\begin{array}{l}\text { Control } \\
(\mathrm{n}=6)\end{array}$ & $176.5(26 \cdot 8)$ & $16 \cdot 0(4 \cdot 6)^{\mathrm{a}}$ & $16 \cdot 4(5 \cdot 6)$ & $10.9(4 \cdot 2)$ \\
\hline $\begin{array}{l}\text { Hypoxia } \\
(\mathrm{n}=7)\end{array}$ & $62 \cdot 4(15 \cdot 6)$ & $57 \cdot 8(12 \cdot 6)$ & $2 \cdot 0(0 \cdot 7)^{b}$ & $101 \cdot 0(37 \cdot 4)^{\mathrm{b}}$ \\
\hline $\begin{array}{l}\text { Ischaemia } \\
(\mathrm{n}=8)\end{array}$ & $99 \cdot 8(27 \cdot 4)$ & $53.8(19 \cdot 9)$ & $2 \cdot 4(0 \cdot 6)^{b}$ & $86 \cdot 0(27 \cdot 3)^{b}$ \\
\hline
\end{tabular}

tConversion of ANG I $(\%)=\left(\mathrm{ED}_{\text {5OANG II }} / \mathrm{ED}_{\text {50ANG }}\right) \times 100$.

aP >0.05 v $\mathrm{ED}_{50 \mathrm{NGl}}$; ${ }^{\mathrm{P}} \mathrm{P}<0.05 v$ control (Tian $\mathrm{R}$, et al, $1991^{22}$ ).
$\left(\mathrm{AT}_{1}\right)$ receptor antagonist (losartan) induced greater coronary vasodilatation than an $\mathrm{ACE}$ inhibitor (enalaprilat), and substantially augmented coronary blood flow. ${ }^{31}$ In rats, sodium depleted dogs, patients pretreated with the diuretic frusemide, and patients with renovascular hypertension which resulted in activation of the renin-angiotensin system, coronary blood flow increased following treatment with converting enzyme inhibitor or angiotensin II receptor antagonist proportionally to pretreatment plasma renin activity. 27283233

\section{Pathological conditions}

\section{HYPOXIA}

Perfusion of the isolated rat heart with hypoxic buffer resulted in an increase in coronary flow and reduced the effect of both angiotensin I and angiotensin II on coronary blood flow. ${ }^{22}$ However, during hypoxia, the effect of angiotensin I was almost identical to that of angiotensin II, and the conversion calculated by ED50 was approximately $100 \%$ (table). Reoxygenation restored the effects of angiotensin I and angiotensin II to control levels, suggesting a reversible rearrangement of the angiotensin II receptor or its second messengers, release of an antagonist to angiotensin II, or upregulation of converting enzyme activity, respectively. In other studies, captopril, enalapril, and ramiprilat increased coronary flow during hypoxia in isolated rat hearts and prevented a fall of coronary flow, which occurred after 15 minutes of hypoxia. ${ }^{34}$ The ACE inhibitor teprotide increased myocardial blood flow in intact hypoxic dogs, ${ }^{28}$ suggesting potential control of coronary blood flow by angiotensin II under these conditions.

\section{ISCHAEMIA}

In the isolated rat heart, the effect of angiotensin II on coronary vessels was unaffected by ischaemia, while the effect of angiotensin I was enhanced. These data indicate that conversion of angiotensin I was increased to more than $80 \%$ in the ischaemic isolated heart from approximately $10 \%$ in the control. ${ }^{22}$ During one hour of perfusion, ACE inhibitors increased coronary flow. ${ }^{35}$ The angiotensin II receptor blocker saralasin had no effect on coronary blood flow in the ischaemic isolated heart, arguing against a potential role of locally released angiotensin II on coronary vascular tone. ${ }^{22}$ When angiotensin I was infused into isolated hearts to reduce coronary flow, this flow reduction could be prevented by captopril. ${ }^{36}$

In dogs with coronary blood flow controlled by a coronary cannula, the vasoconstrictor effect of angiotensin I and angiotensin II was attenuated by a reduction of coronary perfusion pressure, which induced ischaemia. ${ }^{37}$ However, in other models of myocardial ischaemia, an activation of the renin-angiotensin system has been shown. ${ }^{37-42}$ In intact models, increased availability of angiotensin II at the receptor is likely and may be responsible for an attenuated response to exogenous angiotensin II by the coronary vascular sys- 
tem. An effect of inhibitors of the reninangiotensin system on coronary blood flow can also be shown in these models.

Several studies employing the use of ACE inhibitors have suggested a role for angiotensin II in blood flow regulation during ischaemia. In anaesthetised dogs, plasma renin activity and angiotensin II concentrations were increased above control as early as 30 seconds after coronary occlusion. ${ }^{37}$ When coronary occlusion was released, characteristic reactive hyperaemia occurred with flow repayment and lactate production. ${ }^{37}$ When the animals were pretreated with the ACE inhibitor captopril or the angiotensin II receptor antagonist saralasin, coronary flow repayment and lactate production were significantly reduced, supporting a potential role for angiotensin II in blood flow regulation during ischaemia. When coronary occlusion was maintained for 15 to 30 minutes, the increase in plasma renin activity persisted. ${ }^{3941}$ Both the ACE inhibitor captopril and the angiotensin II receptor antagonist saralasin significantly increased myocardial blood flow to regions surrounding the ischaemic zone, but not in the centre of ischaemia, and had no effect in sham operated animals without coronary occlusion. In the same model, six hours after coronary occlusion plasma renin activity was still increased, and both the ACE inhibitor and the angiotensin II antagonist increased coronary blood flow over control and reduced systemic vascular resistance and left atrial pressure. ${ }^{42}$ In animals in which nephrectomy was performed three hours before coronary occlusion, captopril had no effect on perfusion of viable myocardium and reduced perfusion of the centre ischaemic zone. ${ }^{39}$ Unloading of the heart, while improving coronary blood flow, was probably responsible for a reduction of myocardial infarct size in this model. In an isolated heart model of coronary occlusion (for

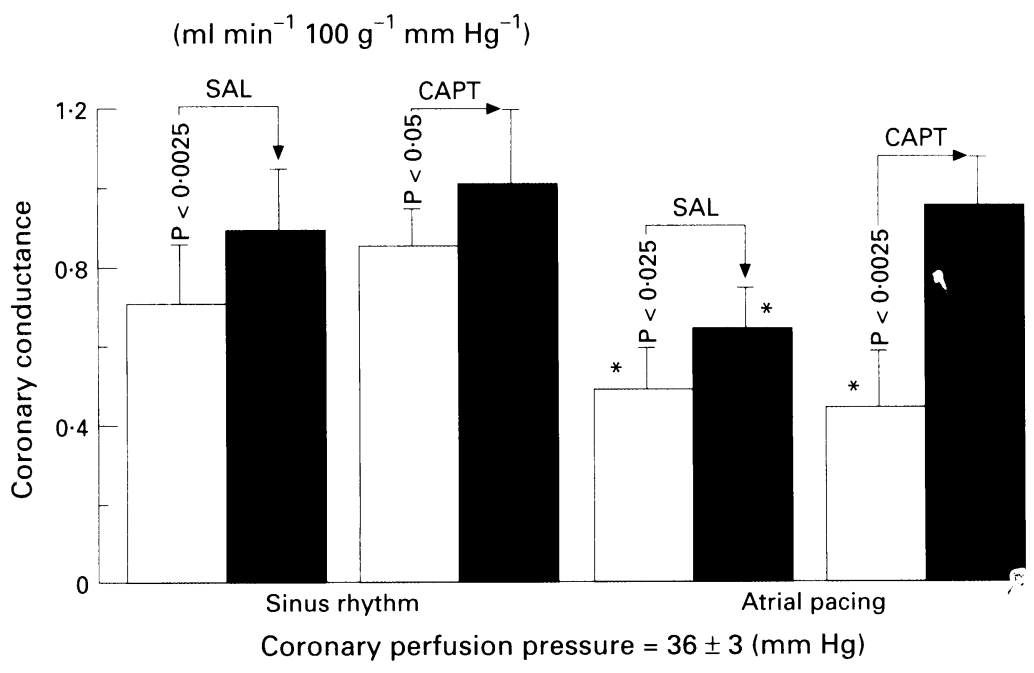

Figure 2 The effect of saralasin ( $0 \cdot 1 \mu \mathrm{g} / \mathrm{kg}$ per min, intracoronary) and captopril $(0 \cdot 25$ $\mathrm{mg} / \mathrm{kg}$ intravenous) on coronary conductance at low coronary perfusion pressure during sinus rhythm and atrial pacing. Both saralasin (SAL) and captopril (CAPT) increased coronary conductance during sinus rhythm and atrial pacing. Atrial pacing reduced coronary conductance at low coronary perfusion pressure (Ertl $\left.G, 1987^{37}\right) .{ }^{\star} P<0.01 \mathrm{v}$ sinus rhythm $(n=6)$.
20 minutes) and reperfusion, pretreatment with the ACE inhibitor ramiprilat or the angiotensin II receptor antagonist losartan resulted in substantial improvement of coronary blood flow in the reperfusion phase. $.^{13}+5$ In the most recent studies, ACE inhibitors showed some survival benefit in patients with acute myocardial infarction. ${ }^{46} 47$ In patients with acute myocardial infarction, plasma renin activity and angiotensin II may increase. ${ }^{48}{ }^{19}$ The effect of inhibitors of the reninangiotensin system on coronary circulation of patients with acute infarcts is unknown.

In a model with graded reduction and control of coronary blood flow by a coronary cannula in the left anterior descending coronary artery of anaesthetised dogs, pacing to increase heart rates induced myocardial ischaemia, as indicated by a reduction of regional myocardial function and an increase in plasma renin activity. ${ }^{37}$ to Pacing in animals without critical reduction of coronary blood flow did not result in an increase in plasma renin activity. ${ }^{40}$

Saralasin and captopril increased coronary conductance when coronary perfusion pressure was lowered to $36 \mathrm{~mm} \mathrm{Hg}$, but had no effect on normal coronary perfusion (fig 2). When pacing was repeated during infusion of an ACE inhibitor or an angiotensin II antagonist, respectively, coronary blood flow and regional myocardial function were preserved. ${ }^{37}$ In studies where coronary perfusion pressure was not maintained constant, ACE inhibitors tended to reduce coronary flow along with a reduction of loading and arterial pressure..$^{51}$ In patients with hypertension and angina, the ACE inhibitor captopril reduced the rate-pressure product and had no effect on coronary vascular resistance..$^{52}$ Changes of coronary flow were proportional to the decrease in rate-pressure product, blood pressure, and myocardial oxygen consumption. ${ }^{52}$ Intravenous captopril tended to increase coronary blood flow and to decrease coronary vascular resistance in patients with stable angina pectoris. ${ }^{53}$ In patients with dilated cardiomyopathy, the ACE inhibitor enalaprilat increased coronary blood flow when the drug was given directly into the coronary circulation. Intravenous enalaprilat or oral captopril reduced the ratepressure product in patients with heart failure and coronary arteriovenous oxygen extraction, suggesting a relative increase in coronary blood flow..$^{29} 555$ However, ACE inhibition did not generally alleviate symptoms in patients with angina pectoris, suggesting that its potential effect on coronary blood flow and myocardial oxygen consumption did not translate into an antianginal efficacy. ${ }^{56}$

Global coronary blood flow to isolated rat hearts is unaltered in the chronic phase postmyocardial infarction, ${ }^{5758}$ and the effect of angiotensin I and angiotensin II is unchanged. $^{57}$ In patients with chronic coronary heart disease and ischaemic response in thallium-201 scintigraphy, plasma renin activity and ACE activity increased during bicycle exercise stress testing..$^{59}$ In these patients, infusion of saralasin or oral cilazapril or captopril resulted in redistribution of thallium-201 or 

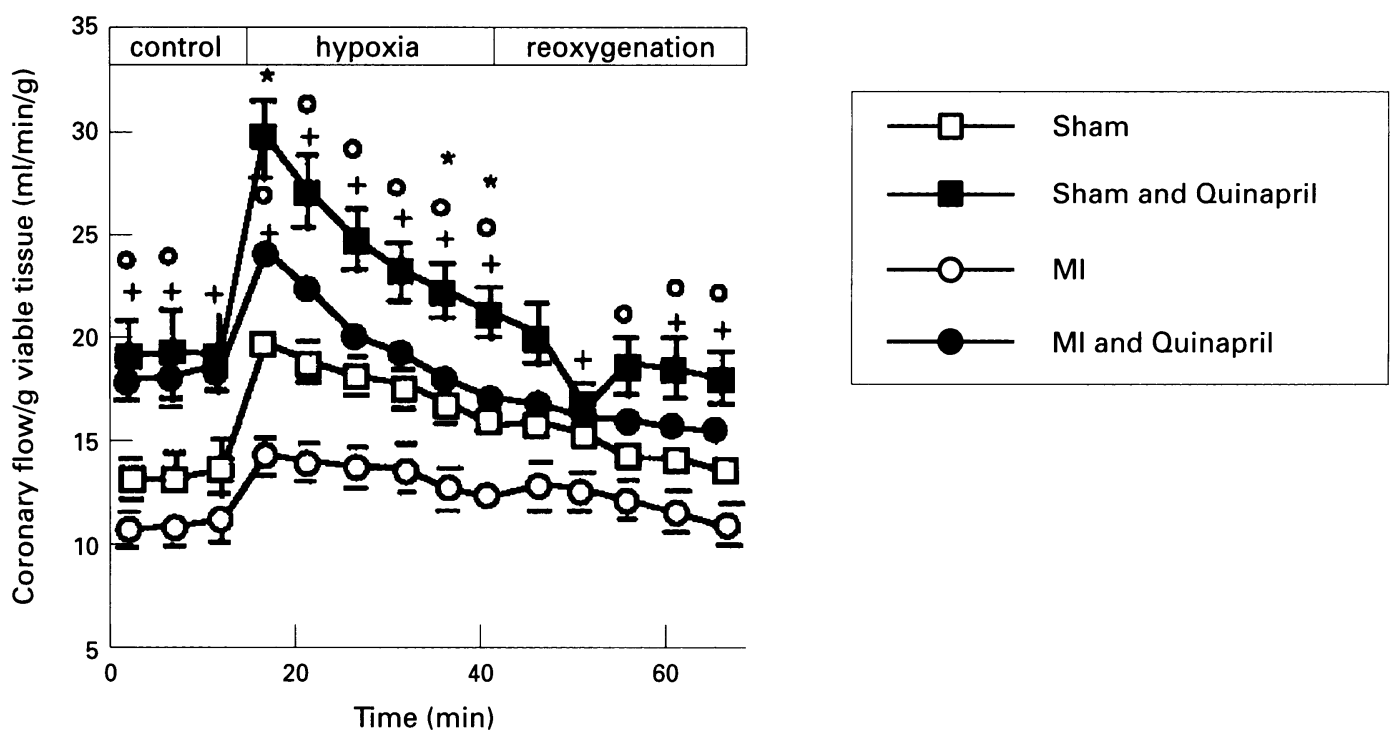

Figure 3 Coronary flow of untreated and quinapril treated sham and myocardial infarction (MI) hearts during the protocol of control (0-15 min), hypoxia (15-45 min), and reoxygenation (45-75 min) periods. ${ }^{58} \star_{P}<0.05$, sham $v \mathrm{MI}$; $\bigcirc P<0.05$, sham $v$ sham and quinapril; $+P<0.05, M I v M I$ and quinapril. (Horm $M$, et al, 1996. ${ }^{58}$ )

Tc99mMIBIN to the cold spot in the scintigram. ${ }^{59}$ Thus, taken together, these results suggest that angiotensin II may control coronary blood flow under certain circumstances and in various models with myocardial ischaemia.

\section{Potential of the renin-angiotensin system for chronic modulation of coronary} vasomotion

Angiotensin II stimulates growth of cardiac myocytes, fibroblasts, and vascular smooth muscle cells. ${ }^{61}$ Functional and morphological changes of endothelial cells, hypertrophy of smooth muscle cells, and accumulation of perivascular fibrosis may interfere with coronary vasomotion. In fact, coronary flow reserve is impaired in various models of cardiac hypertrophy. Quantitative morphological changes occur in the capillary/muscle relation in human hearts during normal growth, with a reduction of capillary density. ${ }^{62}$ Various types of hypertrophy result in a further reduction of the concentration of capillaries or arterioles. $^{62-66}$ Coronary vasodilator reserve is restricted in models of cardiac hypertrophy, such as rats and dogs with renovascular hypertension, ${ }^{64}{ }^{67}$ rats with aortic banding ${ }^{68-72}$ or valvar aortic stenosis, ${ }^{73}$ and in patients with essential arterial hypertension. ${ }^{74}$ Restriction of coronary flow or exhaustion of coronary flow reserve has also been observed in animals and humans with hypertrophy after myocardial infarction ${ }^{5875-77}$ and in heart failure. ${ }^{78-82}$ In addition, it has been suggested that subendocardial ischaemia perpetuates myocardial failure in patients with non-ischaemic congestive cardiomyopathy. ${ }^{79} 8083$ It is remarkable in this context that a shift of lactate dehydrogenase enzymes towards the anaerobic lactate metabolism indicates chronic hypoxia in patients with dilated cardiomyopathy ${ }^{84}$ and in models of cardiac failure.$^{85}{ }^{86}$ Perivascular fibrosis may have a major impact on restriction of blood flow in chronic hypertrophy and cardiac failure. Prevention of collagen deposition by $\beta$ aminoproprionitrile normalised vasodilator reserve in rats with ascending aortic banding. ${ }^{68}$ In dogs with aortic banding and chronic heart failure due to arteriovenous shunt, increased fibrosis in the endocardial layers was associated with an exhausted endocardial blood flow reserve. ${ }^{78}$ In addition, coronary reserve seems to be determined by medial hypertrophy in rats with aortic banding. ${ }^{68}$

How might the renin-angiotensin system be involved in these processes, and thus chronically alter coronary vasomotion? The $\mathrm{AT}_{1}$ receptors mediate both vasoconstrictor and hypertrophic responses in smooth muscle cells. ${ }^{87}$ In addition, fibroblasts express $\mathrm{AT}_{1}$ receptors, which control fibroblast growth..$^{88}$ Thus, angiotensin II may control both medial hypertrophy and collagen deposition in the heart.

Inhibitors of the renin-angiotensin system, both at the converting enzyme and at the receptor level, reduce vascular media hypertrophy ${ }^{90}$ and may prevent neointima formation in certain models of coronary injury..$^{91-94}$ The MERCATOR trial, however, failed to show a preventative effect of the ACE inhibitor cilazapril on restenosis after percutaneous transluminal coronary angioplasty. ${ }^{95}$

Inhibitors of the renin-angiotensin-aldosterone system reduce fibrosis in various models of hypertrophy, including hypertension and hypertrophy of surviving myocardium after myocardial infarction. ${ }^{969}$ The response to angiotensin I and angiotensin II was unaffected in these hearts. ${ }^{57}$ Chronic treatment with the ACE inhibitor quinapril increased coronary flow in both sham operated and infarcted hearts (fig 3)..$^{58}$ It also completely restored the hyperaemic response to hypoxia, which is severely depressed in the heart after myocardial infarction. ${ }^{58}$ However, as stated 


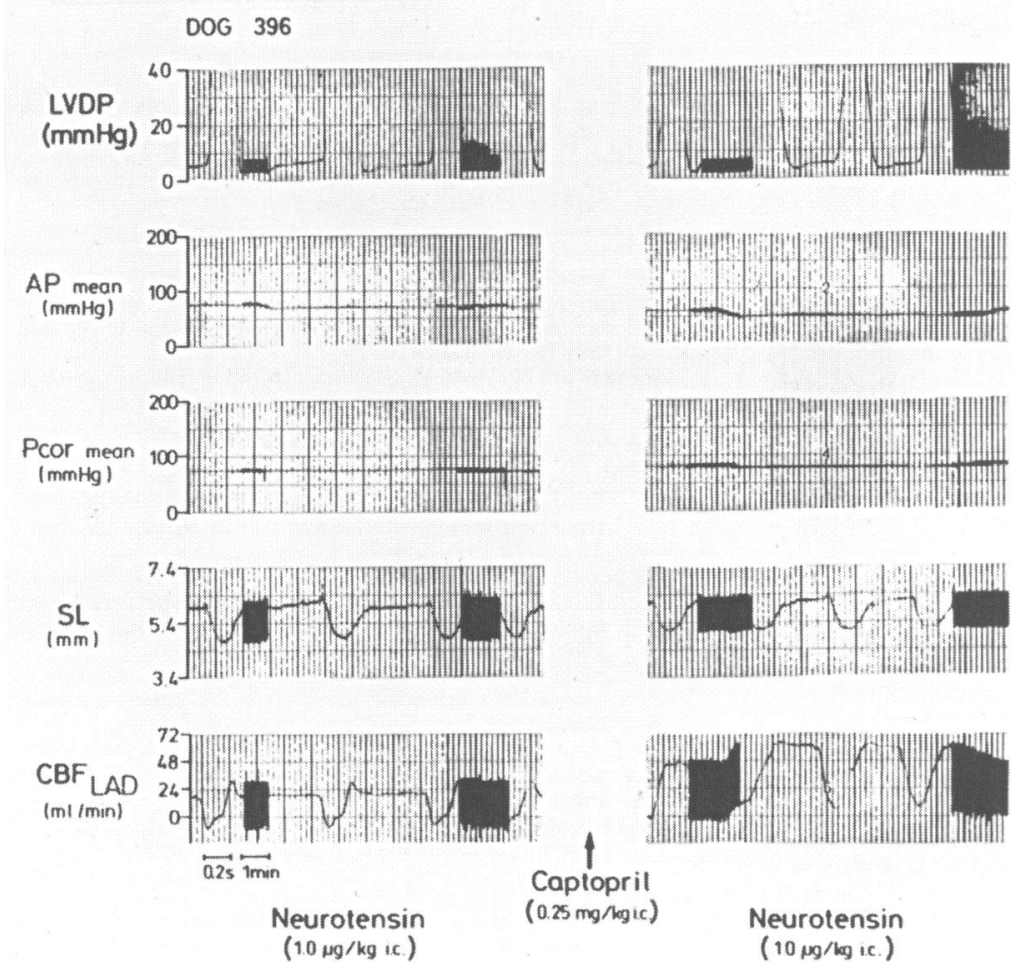

Figure 4 Original recording of a protocol using neurotensin $(1.0 \mu \mathrm{g} / \mathrm{kg}$ intracoronary [ic]) before and after the angiotensin converting enzyme inhibitor captopril $(0.25 \mathrm{mg} / \mathrm{kg}$ intracoronary). Left ventricular diastolic pressure (LVDP) and subendocardial segment length (SL) were unchanged by neurotensin, whereas aortic pressure decreased. Coronary perfusion pressure $\left(P_{\text {cor }}\right.$ mean) was held constant by design. After captopril, neurotensin increased coronary blood flow $(C B F)$, whereas only minor changes in $C B F$ were noted before captopril (Bauer B, et al, 1995

above, the effect of ACE inhibitors is non-specific and does not provide a role for angiotensin II in these processes. Studies using specific $\mathrm{AT}_{1}$ receptor antagonists are needed to identify a potential role for angiotensin II in the chronic modification of coronary vasomotion.

\section{Interaction of the renin-angiotensin system with other mediators controlling coronary vasomotion}

The renin-angiotensin system is related to other vasoactive mediators at different levels of the renin-angiotensin cascade. Best known is the pluripotentiality of ACE, a carboxypeptidase which degrades a number of vasoactive peptides. Most studies have focused on the bradykinin degradation, but hydrolysis of the neuropeptides substance $P$ and neurotensin has been shown in vitro. ${ }^{98}$ Inhibition of ACE potentiates the effect of neurotensin on coronary circulation in dogs (fig 4). ${ }^{99}$ It has been shown that the ACE inhibitor captopril also reversed the long term "tonic" vasoconstrictor effects of endothelin-1 on coronary circulation in dogs. ${ }^{99} \mathrm{ACE}$ inhibitors attenuated the maximum coronary vasoconstrictor response to the highest doses of endothelin-1 in isolated perfused rat heart, but did not shift the doseresponse curve of endothelin-1. ${ }^{100}$ However, angiotensin II also directly interacts with the sympathetic nervous system. ${ }^{101}$ Pressure response to sympathetic stimulation and noradrenaline infusion is amplified by angiotensin
II and reduced by ACE inhibition. In isolated rabbit hearts, reduction of coronary blood flow induced by stellate ganglion stimulation was attenuated by ACE inhibition. ${ }^{102}$ ACE inhibition attenuates sympathetic coronary vasoconstriction in patients with coronary artery disease, ${ }^{102}$ suggesting a potentiating role for angiotensin II on sympathetic influence of coronary circulation. These observations may be of clinical relevance, since inhibitors of the renin-angiotensin system may exert their long term beneficial effects on survival and may reduce the incidence of myocardial infarction or ischaemic complications in part by their interference with the sympathetic nervous system.

The ACE inhibitors captopril and enalaprilat enhanced coronary blood flow in pigs subjected to 30 minutes of left anterior descending coronary artery occlusion followed by one hour of reperfusion. In addition, investigators preserved endothelium dependent microvascular relaxation, tested by adenosine diphosphate (ADP) and the calcium ionophore A23187, during reperfusion. ${ }^{104}$

Atrial natriuretic factor (ANF) acts as a vasodilator in most preparations including studies in the human. However, the effect on the coronary circulation depends on the preexisting ANF plasma concentrations and the activities of the renin-angiotensin system. ${ }^{105}$ The ACE inhibitor captopril and the angiotensin II receptor antagonist saralasin, infused directly into the coronary artery of anaesthetised dogs, abolished the vasodilator effect of ANF. ${ }^{105}$ In isolated rat hearts, infusion of angiotensin II potentiated the coronary vasodilator effect of $A N F$, while the ACE inhibitor captopril and the angiotensin II receptor antagonist saralasin abolished the coronary vasodilator effect of ANF (fig 5). ${ }^{106}$ Thus the renin-angiotensin system may influence coronary vasomotion by interactions with various other mediator systems, including the sympathetic nervous system, endothelium dependent mechanisms, and ANF. However, we are far from understanding the quantitative importance of these mechanisms or their clinical relevance at this time.

\section{Conclusion}

The physiological significance of angiotensin II on coronary vasomotion is unclear. Most studies have shown that in individuals without an activation of the renin-angiotensin system, a vasoconstrictor tone of angiotensin II does not exist on the coronary vascular system. When the renin-angiotensin system is activated by dietary sodium deprivation, diuretics, Goldblatt mechanism, heart failure, or myocardial ischaemia, angiotensin II gains control over coronary blood flow. Beneficial effects of inhibitors of the renin-angiotensin system in numerous models suggest a pathophysiological role of angiotensin II under these conditions. Recent studies showing a preventative effect of ACE inhibitors on acute coronary syndromes may support this hypothesis. Additionally, angiotensin II may influence 


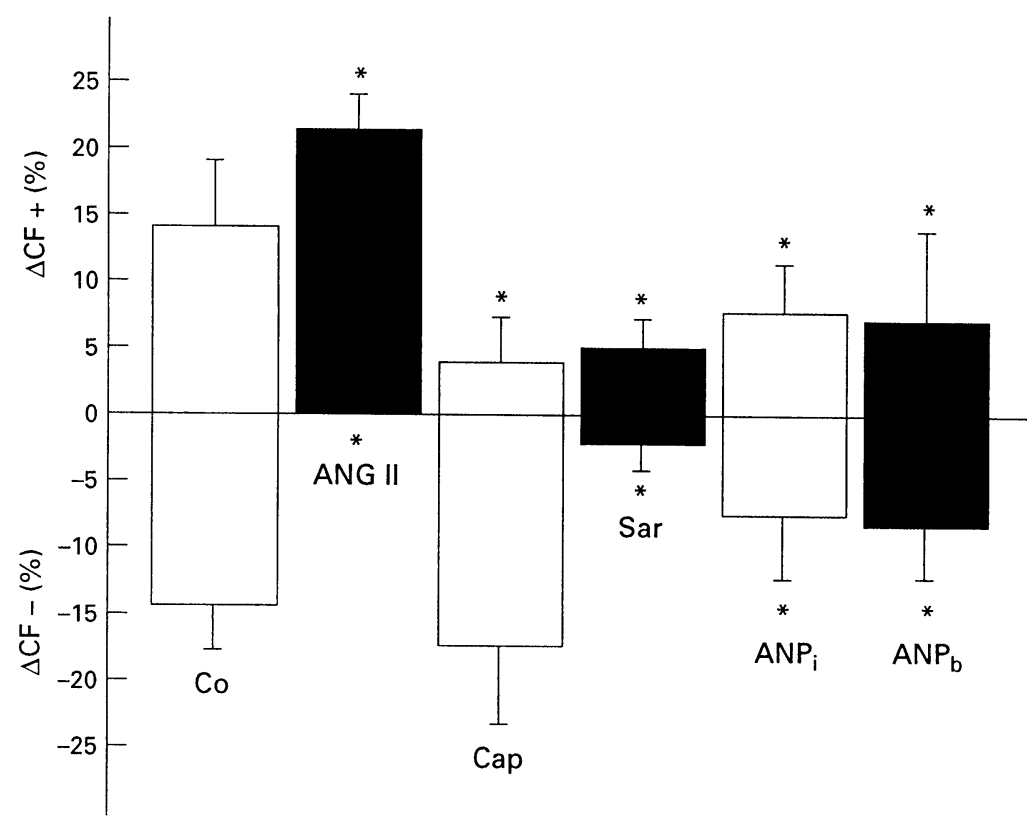

Figure 5 Maximum coronary flow increase $(C F+)$ and decrease $(C F-)$ after $40 \mathrm{nmol}$ atrial natriuretic factor $(A N F)$ bolus administration in control group (Co) and groups receiving pretreatment: angiotensin $I I$ (ANG II), captopril (Cap), saralasin (Sar), ANP infusion $(A N P)$, or $A N P$ bolus $\left(A N P_{i}\right)$. Variations are related to values--after stabilisation for the control group-in the new steady state for groups receiving pharmacological pretreatment. ${ }^{\star} P<0.05$ v control group (Bauer WR, et al, 1994 $\left.4^{\prime \prime \prime}\right)$.

coronary vasomotion by its chronic effects on cardiac and coronary morphology. Coronary arterial medial hypertrophy, intima hyperplasia in coronary lesions, and perivascular fibrosis may influence coronary vasomotion in cardiac hypertrophy, coronary heart disease, and heart failure. The clinical relevance of these observations remains unknown.

GE acknowledges his support from the SFB 355 "Pathophysiologie der Herzinsuffizienz", Würzburg, and from the Forschungsfond der Fakultät für Klinische Medizin Mannheim, Universität Heidelberg, for this paper and the studies included in this paper. The secretarial work of Ms Haag is very much appreciated.

1 Bristow JD, McFalls EO, Anselone CG, Pantley GA. Coronary vasodilator reserve persists despite tachycardia and myocardial ischemia. Am $f$ Physiol 1987;253: $\mathrm{H} 422-31$

2 Canty JM, Klocke FJ. Reduced regional myocardial perfusion in the presence of pharmacologic vasodilator reserve. Circulation 1985;71:370-7.

3 Csik V, Szekeres L, Udvary E. Drug-induced augmentation of coronary flow in vessels with maximum ischemic dilatation. Arch Int Pharmacodyn Ther 1976;224:66 76.

4 Frame LH, Powell WJ. Progressive perfusion impairment during prolonged low flow myocardial ischemia in dogs. Circ Res 1976;39:269-76.

5 Gorman MW, Sparks HV. Progressive coronary vasoconstriction during relative ischemia in canine myocardium. Circ Res 1982;51:411-20.

6 Guyton RA, McClenathan JH, Michaelis LL. Evolution of regional ischemia distal to a proximal coronary stenosis: self-propagation of ischemia. Am $\mathcal{F}$ Cardiol 1977;40: sis: self-pro.

7 Hellstrom HR. Coronary artery stasis after induced myocardial infarction in the dog. Cardiovasc Res 1971;5: myocar $371-5$.

8 Laxson DD, Dai XZ, Homans DC, Bache RJ. Coronary vasodilator reserve in ischemic myocardium of the exercising dog. Circulation 1992;85:313-22.

9 Parodi O, Sambuceti G, Roghi A, Testa R, Inglese E, Pirelli S, et al. Residual coronary reserve despite decreased resting blood flow in patients with critical coronary lesions. A study by technetium $-99 \mathrm{~m}$ human albumin microsphere myocardial scintigraphy. Circulation 1993;87:330-44

10 Pupita G, Maseri A, Kaski JC, Galassi AR, Gavrielides S, Davies G, et al. Myocardial ischemia caused by distal coronary-artery constriction in stable angina pectoris. $N$
Engl f Med 1990;323:514-20.

11 Aversano T, Becker LC. Persistence of coronary vasodilator reserve despite functionally significant flow reduction. Am f Physiol 1985;248:H403-11.

12 Feigl EO. The paradox of adrenergic coronary vasoconstriction. Circulation 1987;76:737-45.

13 Ertl G, Wichmann J, Steinke E, Lochner W. On the range of alpha-adrenergic regulation of coronary vascular resistance. Basic Res Cardiol 1979;74:456-66.

14 Heusch G, Deussen A. The effects of cardiac sympathetic nerve stimulation on perfusion of stenotic coronary nerve stimulation on perfusion of sten
arteries in the dog. Circ Res 1983;53:8-15.

15 Buffington CW, Feigl EO. Adrenergic coronary vasoconstriction in the presence of coronary stenosis in the dog. $981 ; 48: 416-23$.

16 Gewirtz H, Most AS, Williams DO. The effect of generalized alpha-receptor stimulation on regional myocardial blood flow distal to a severe coronary artery stenosis. Circulation 1982;65:1329-36.

17 Mudge GH, Grossman W, Mills RM, Lesch M, Braunwald E. Reflex increase in coronary vascular resistance in patients with ischemic heart disease. $N$ Engl $\mathcal{F}$ Med 1976;295:1333-7.

18 Seitelberger R, Guth BD, Heusch G, Lee JD, Katayama $\mathrm{K}$, Ross J. Intracoronary 2-adrenergic receptor blockade attenuates ischemia in conscious dogs during exercise. Circ Res 1988;62:436-42.

19 Ertl G, Fuchs M. Alpha-adrenergic vasoconstriction in arterial and arteriolar sections of the canine coronary circulation. Basic Res Cardiol 1980;75:600-14

20 Britton S, Di Salvo J. Effects of angiotensin I and angiotensin II on hindlimb and coronary vascular resistance. Am f Physiol 1973;225:1226-31.

21 Gerlings ED, Gilmore JP. Evidence for myocardial conversion of angiotensin I. Basic Res Cardiol 1974;69: $222-7$.

22 Tian $R$, Neubauer $S$, Pulzer $F$, Haas $U$, Ertl $G$. Angiotensin I conversion and coronary constriction by
angiotensin II in ischemic and hypoxic isolated rat angiotensin II in ischemic and hypo

23 Whelan RF, Scroop GC, Walsh JA. Cardiovascular actions of angiotensin in man. Am Heart $\mathcal{F}$ 1969;77: $546-65$

24 Magrini F. Determinants of coronary blood flow: autonomic versus renin-angiotensin system. In: Zusman RM, ed. Cardioprotection by converting enzyme inhibition. New York: Excerpta Medica, 1988:39-42

25 Yamada H, Fabris B, Allen AM, Jackson B, Johnston CI, Mendelsohn AO. Localization of angiotensin converting enzyme in rat heart. Circ Res 1991;68:141-9.

26 Pinto JE, Viglione P, Saavedra JM. Autoradiographic localization and quantification of rat heart angiotensin converting enzyme. Am f Hypertens 1991;4:321-6.

27 Gavras H, Faxon DP, Berkoben J, Brunner HR, Ryan TJ. Angiotensin converting enzyme inhibition in patients with congestive heart failure. Circulation 1978;58:770-6.

28 Liang CS, Gavras H. Renin-angiotensin system inhibition in conscious dogs during acute hypoxemia. Effects on systemic hemodynamics, regional blood flows, and tissue metabolism. F Clin Invest 1978;62:961-70.

29 Faxon DP, Creager MA, Halperin JL, Sussman HA, Gavras H, Ryan TJ. The effect of angiotensin converting enzyme inhibition of coronary blood flow and hemodynamics in patients without coronary artery disease. Int $\mathcal{f}$ namics in patients without

30 Holtz J, Busse R, Sommer O, Bassenge E. Dilation of epicardial arteries in conscious dogs induced by angiotensin-converting enzyme inhibition with enalaprilat. $\mathcal{F}$ Cardiovasc Pharmacol 1987;9:348-55.

31 Sudhir K, MacGregor JS, Gupta M, Barbant SD, Redberg R, Yock PG, et al. Effect of selective angiotensin II receptor antagonism and angiotensin converting enzyme inhibition on the coronary vasculature in vivo. Intravascular two-dimensional and Doppler ultrasound studies. Circulation 1993;87:931-8.

32 Magrini F, Shimizu M, Roberts N, Fouad FM, Tarazi RC, Zanchetti A. Converting- enzyme inhibition and coronary blood flow. Circulation 1987;75:I168-74

33 Magrini F, Reggiani P, Roberts N, Meazza R, Ciulla M, Zanchetti A. Effects of angiotensin and angiotensin blockade on coronary circulation and coronary reserve. Am $\mathcal{F}$ Med 1988;84:55-60.

34 Mezzetti A, Scarinci A, Parlangeli C, ProiettiFranceschilli G, Guglielmi MD, Mancini $M$, et al. Angiotensin-converting enzyme inhibitors counteract hypoxia-induced coronary constriction in the isolated rat heart. Curr Therapeu Res 1990;48:1075 86.

35 Rump AF, Rösen R, Korth A, Klaus W. Deleterious effect of exogenous angiotensin-I on the extent of regional of exogenous angiotensin-1 on the extent of regional
ischaemia and its inhibition by captopril. Eur Heart 7 ischaemia and its

36 van Gilst WH, Scholtens E, de Graeff PA, de Langen CD, Wesseling $\mathrm{H}$. Differential influences of angiotensin conWesseling $\mathrm{H}$. Differential influences of angiotensin converting-enzyme inhibitors

37 Ertl G. Coronary vasoconstriction in experimental myocardial ischemia. 7 Cardiovasc Pharmacol 1987;9 (suppl 2):S9-17.

38 Ertl G, Bauer B. Coronary arteriolar vasoconstriction in myocardial ischaemia. Vasopressin, renin-angiotensin system and ANF. Eur Heart f 1990; 11 (suppl B):53 7 .

39 Ertl G, Alexander RW, Kloner RA. Interactions between coronary occlusion and the renin-angiotensin system in the dog. Basic Res Cardiol 1983;78:518-33. 
40 Ertl G, Meesmann M, Kochsiek K. On the mechanism of Eur 7 Clin Invest 1985;15:375-81.

41 Santos RA, Brum JM, Brosnihan KB, Ferrario CM. The renin-angiotensin system during acute myocardial ischemia in dogs. Hypertension 1990;15:1121-7.

42 Ertl G, Kloner RA, Alexander RW, Braunwald E. Limitation of experimental infarct size by an angiotensin-contion of experimental infarct size by an angiotensin-

43 Liu YH, Yang XP, Sharov VG, Sigmon DH, Sabbath HN, Carretero OA. Paracrine systems in the cardioproinhibitors on myocardial ischemia/reperfusion injury in inhibitors on myocardial ischemiat

44 Linz W, Schölkens BA, Han YF. Beneficial effects of the converting enzyme inhibitor, ramipril, in ischemic rat hearts. $\mathcal{F}$ Cardiovasc Pharmacol 1986;8(suppl 10):S91-9.

$45 \mathrm{Linz}$ W, Schölkens BA. Influence of local converting enzyme inhibition on angiotensin and bradykinin effects in ischemic rat hearts. $\mathcal{F}$ Cardiovasc Pharmacol 1987;10 (suppl 7):S75-82.

46 ISIS-4 (Fourth International Study of Infarct Survival) Collaborative Group. ISIS-4: a randomised factoria trial assessing early oral captopril, oral mononitrate, and intravenous magnesium sulfate in 58,050 patients with suspected acute myocardial infarction. Lancet 1995;345: 669-85.

47 Gruppo Italiano per lo Studio della Sopravvivenza nell'infarto Miocardio. GISSI-3: effects of lisinopril and transdermal glyceryl trinitrate singly and together on 6week mortality and ventricular function after acute myocardial infarction. Lancet 1994;343:1115-22.

48 Michorowski B, Ceremuzynski L. The renin-angiotensinaldosterone system and the clinical course of acute aldosterone system and the clinical course of a

49 McAlpine HM, Morton J, Leckie B, Dargie HJ. Haemodynamic effects of captopril in acute left ventricular failure complicating myocardial infarction. $\mathcal{F}$ Cardiovasc Pharmacol 1987;9(suppl 2):S25-30.

50 Bache RJ, Dai XZ, Baran KW. Effect of pinacidil on myocardial blood flow in the presence of a coronary artery stenosis. F Cardiovasc Pharmacol 1990;15:618-25.

51 Berdeaux A, Bonhenry C, Giudicelli JF. Effects of four angiotensin I converting enzyme inhibitors on regional myocardial blood flow and ischemic injury during coronary artery occlusion in dogs. Fund Clin Pharmacol 1987;1:201-12.

52 Daly P, Rouleau JL, Cousineau D, Burgess JH. Acute effects of captopril on the coronary circulation of patients with hypertension and angina. Am $\mathcal{F} M e d 1984$ 76:111-5.

53 Ikram H, Low CJ, Shirlaw T, Webb CM, Richards AM, Crozier IG. Antianginal, hemodynamic and coronary vascular effects of captopril in stable angina pectoris. $\mathrm{Am}$ vascular effiol 1990;66:164-7.

54 DeMarco T, Daly PA, Liu M, Kayser S, Parmley WW, Chatterjee K. Enalaprilat, a new parenteral angiotensinconverting enzyme inhibitor: rapid changes in systemic and coronary hemodynamics and humoral profile in chronic heart failure f Am Coll Cardiol 1987;9:1131-8.

55 Rouleau JL, Chatterjee K, Benge W, Parmley WW, Hiramatsu B Alterations in left ventricular function and coronary hemodynamics with captopril, hydralazine and prazosin in chronic ischemic heart failure: a comparative study. Circulation 1982;65:671-8.

56 Ertl G. Angiotensin converting enzyme inhibitors in angina and myocardial infarction. What role will they play in the 1990s? Drugs 1993;46:209-18.

57 Han H, Tian R, Neubauer S, Gaudron P, Hu K, Ertl G Effects of LTD4 and its specific antagonist L-660,711 in isolated rat hearts with chronic myocardial infarction Am f Physiol 1994;266: H2068-73.

58 Horn M, Neubauer S, Frantz S, Hügel S, Hu K, Gaudron $P$, et al. Preservation of left ventricular mechanical function and energy metabolism in rats after myocardial infarction by the angiotensin-converting enzyme 201-10.

59 Ertl G, Bauer B, Gaudron P, Neubauer S, Schorb W, Kochsiek K. Möglichkeiten einer ACE-HemmerTherapie bei akuter Myokardischämie. Klin Wochenschr 1991;69 suppl 24:10-9.

60 Gasic S, Dudczak R, Korn A, Kleinbloesem C. ACE inhibition with cilazapril improves myocardial perfusion to the ischemic regions during exercise: a pilot study. $\mathcal{F}$ the ischemic regions during exercise:

61 Pratt RE, Dzau VJ. Pharmacological strategies to prevent restenosis: lessons learned from blockade of the reninrestenosis: lessons learned from blockade of the

62 Roberts JT, Wearn JT. Quantitative changes in the capillary-muscle relationship in human hearts during norma growth and hypertrophy. Am Heart $\mathcal{F}$ 1941;21:617-23.

63 Vitullo JC, Penn MS, Rakusan K, Wicker P. Effects of hypertension and aging on coronary arteriolar density. Hypertension 1993;21:406-14.

64 Müeller TM, Marcus ML, Kerber RE, Young JA, Barnes RW, Abboud FM. Effect of renal hypertension and left ventricular hypertrophy on the coronary circulation in dogs. Circ Res 1978;42:543-9.

65 Anversa P, Ricci R, Olivetti G. Quantitative structura analysis of the myocardium during physiologic growth and induced cardiac hypertrophy: a review. $\mathcal{f} \mathrm{Am}$ Coll Cardiol 1986;7:1140-9.

66 Olivetti G, Capasso JM, Meggs LG, Sonnenblick EH,
Anversa P. Cellular basis of chronic ventricular remodeling after myocardial infarction in rats. Circ Res 1991; 68:856-69.

67 Wicker P, Abdul-Samad M, Rakusan K, Tarazi RC, Healy B. Effects of chronic exercise on the coronary circulation in conscious rats with renovascular hypertension. Hypertension 1987;10:74-81.

68 Isoyama S, Ito N, Satoh K, Takishima T. Collagen deposition and the reversal of coronary reserve in cardiac sition and the reversal of coronary reserve

69 O'Gorman DJ, Thomas P, Turner MA, Sheridan DJ. Investigation of impaired coronary vasodilator reserve in the guinea pig heart with pressure induced hypertrophy. the guinea pig heart with press

70 Malik AB, Geha AS. Cardiac function, coronary flow and $\mathrm{MVO}_{2}$ in hypertrophy induced by pressure and volume overloading. Cardiovasc Res 1977;11:310-6.

71 Gaasch WH, Zile MR, Hoshino PK, Apstein CS, Blaustein AS. Stress-shortening relations and myocardial blood flow in compensated and failing canine hearts with pressure-overload hypertrophy. Circulation 1989; 79:872-83.

72 Duncker DJ, Zhang J, Bache RJ. Coronary pressure-flow relation in left ventricular hypertrophy. Importance of changes in back pressure versus changes in minimum resistance. Circ Res 1993;72:579-87.

73 Vinten-Johansen J, Weiss HR. Oxygen consumption in subepicardial and subendocardial regions of the canine left ventricle. The effect of experimental acute valvular aortic stenosis. Circ Res 1980;46:139-45.

74 Strauer BE. Myocardial oxygen consumption in chronic heart disease: role of wall stress, hypertrophy and coroheart disease: role of wall stress, hypertroph

75 Karam R, Healy BP, Wicker P. Coronary reserve is depressed in postmyocardial infarction reactive cardiac depressed in postmyocardial infarction reac
hypertrophy. Circulation 1990;81:238-46.

76 Uren NG, Crak T, Lefroy DC, de Silva R, Davies GJ, Maseri A. Reduced coronary vasodilator function in infarcted and normal myocardium after myocardial infarction. N Engl fु Med 1994;331:222-7.

77 Nelissen-Vrancken HJ, Debets JJ, Snoeckx LH, Daemen MJ, Smits JF. Time-related normalization of maximal coronary flow in isolated perfused hearts of rats with myocardial infarction. Circulation 1996;93:349-55.

78 Hittinger L, Shannon RP, Bishop SP, Gelpi RJ, Vatner SF. Subendomyocardial exhaustion of blood flow reserve and increased fibrosis in conscious dogs with heart failure. Circ Res 1989;65:971-80.

79 Unverferth DV, Magorien RD, Lewis RP, Leier CV. The role of subendocardial ischemia in perpetuating myocardial failure in patients with nonischemic congestive cardiomyopathy. Am Heart $\mathcal{f}$ 1983;105:176-9.

80 De Marco T, Chatterjee K, Rouleau JL, Parmley WW. Abnormal coronary hemodynamics and myocardial energetics in patients with chronic heart failure caused by ischemic heart disease and dilated cardiomyopathy. Am Heart f 1988;115:809-15.

81 Weiss MB, Ellis K, Sciacca RR, Johnson LL, Schmidt $\mathrm{DH}$, Cannon PJ. Myocardial blood flow in congestive and hypertrophic cardiomyopathy: relationship to peak wall stress and mean velocity of circumferential fiber wall stress and mean velocity of circum

82 Cannon RO III, Cunnion RE, Parrillo JE, Palmeri ST, Tucker EE, Schenke WH, et al. Dynamic limitation of coronary vasodilator reserve in patients with dilated car-
diomyopathy and chest pain. $\Im \mathrm{Am}$ Coll Cardiol 1987; diomyopathy

83 Sonnenblick EH, Fein F, Capasso JM, Factor SM. Microvascular spasm as a cause of cardiomyopathies and the calcium-blocking agent verapamil as potential primary therapy. Am $\mathcal{F}$ Cardiol 1985;55:179-84B.

84 Schultheiss HP, Ullrich G, Schindler M, Schulze K, Strauer BE. The effect of ACE inhibition on myocardial energy metabolism. Eur Heart $f$ 1990;11(suppl B): $116-22$

85 Neubauer S, Horn M, Naumann A, Tian R, Hu K, Laser $\mathrm{M}$, et al. Impairment of energy metabolism in intact dial infarction. $\mathcal{F}$ Clin Invest 1995;95:1092-100.

86 Laser A, Neubauer S, Tian R, Hu K, Gaudron P, Ingwall JS, et al. Long-term beta-blocker treatment prevents chronic creatine kinase and lactate dehydrogenase system changes in rat hearts after myocardial infarction. $f$ tem changes in rat hearts after 1 Cardiol 1996;27:487-93.

87 Chiu AT, Roscoe WA, McCall DE, Timmermans PB Angiotensin II-1 receptors mediate both vasoconstrictor and hypertrophic responses in rat aortic smooth muscle cells. Receptor 1991;1:133-40.

88 Schorb W, Booz GW, Dostal DE, Conrad KM, Chang $\mathrm{KC}$, Baker KM. Angiotensin II is mitogenic in neonatal rat cardiac fibroblasts. Circ Res 1993;72:1245-54.

89 Villarreal FJ, Kim NN, Ungab GD, Printz MP, Dillmann WH. Identification of functional angiotensin II receptors on rat

90 Gibbons GH, Dzau VJ. Angiotensin converting enzyme inhibition and vascular hypertrophy in hypertension. Cardiovasc Drugs Ther 1990;4:237-42.

91 Janiak P, Libert O, Vilaine JP. Role of the reninangiotensin system in neointima formation after injury in rabbits. Hypertension 1994;24:671-8.

92 Clozel JP, Hess P, Michael C, Schietinger K, Baumgartner HR. Inhibition of converting enzyme and neointima formation after vascular injury in rabbits and 
guinea pigs. Hypertension 1991;18:II55-9.

93 Osterrieder W, Müller RK, Powell JS, Clozel JP, Hefti F, Baumgartner HR. Role of angiotensin II in injuryinduced neointima formation in rats. Hypertension 1991;18:II60-4.

94 Powell JS, Müller RK, Rouge M, Kuhn H, Hefti F, Baumgartner $\mathrm{HR}$. The proliferative response to vascular injury is suppressed by angiotensin-converting enzyme inhibition. f Cardiovasc Pharmacol 1990;16(suppl 4): S42-9.

95 Multicenter European Research Trial with Cilazapril after Angioplasty to Prevent Transluminal Coronary Obstruction Restenosis (MERCATOR) Study Group. Does the new angiotensin converting enzyme inhibitor cilazapril prevent restenosis after percutaneous transluminal coronary angioplasty? Results of the MERCA-
TOR study: a multicenter, randomized, double-blind placebo-controlled trial [comment]. Circulation 1992;86: $100-10$

96 Weber KT, Sun Y, Katwa LC, Cleutjens JP. Connective tissue: a metabolic entity (published erratum appears in $\mathcal{F}$ Mol Cell Cardiol 1995;27:1457) f Mol Cell Cardiol 1995;27:107-20

97 Nicoletti A, Heudes D, Hinglais N, Appay MD, Philippe $M$, Sassy-Prigent $C$, et al. Left ventricular fibrosis in renovascular hypertensive rats. Effect of losartan and spironolactone. Hypertension 1995;26:101-11.

98 Skidgel RA, Engelbrecht S, Johnson AR, Erdös EG. Hydrolysis of substance $P$ and neurotensin by converting enzyme and neutral endopeptidase. Peptides 1984;5:
99 Bauer B, Neubauer S, Spindler M, Dürr R, Becker HH, Ertl G. Interference of angiotensin-converting enzyme inhibition with vasoactive peptides in the coronary circulation of dogs. 7 Cardiovasc Pharmacol 1995;25: 756-62.

100 Neubauer S, Ertl G, Haas U, Pulzer F, Kochsiek K. Effects of endothelin-1 in isolated perfused rat heart. $\mathcal{F}$ Cardiovasc Pharmacol 1990;16:1-8.

101 Zimmerman BG, Sybertz EJ, Wong PC. Interaction between sympathetic and renin-angiotensin system. $\mathcal{f}$ Hypertens 1984;2:581-7.

102 Xiang JZ, Schölkens BA, Ganten D, Unger T. Effects of sympathetic nerve stimulation are attenuated by the sympathetic nerve stimulation are attenuated by the hearts. Clin Exp Hypertens $(A)$ 1984;6:1853-7.

103 Perondi R, Saino A, Tio RA, Pomidossi G, Gregorini L, Alessio $\mathrm{P}$, et al. ACE inhibition attenuates sympathetic coronary vasoconstriction in patients with coronary ;85:2004-13.

104 Piana RN, Wang SY, Friedman M, Sellke FW. Angiotensin-converting enzyme inhibition preserves endothelium-dependent coronary microvascular responses during short-term ischemia-reperfusion. Circulation 1996;93:544-51.

105 Ertl G, Bauer B, Gaudron P, Kolb M, Kochsiek K. Determinants of coronary effects of atrial natriuretic factor in dogs. Eur $\mathcal{F}$ Clin Invest 1992;22:516-22.

106 Bauer WR, Neubauer S, Obitz G, Ertl G. Interrelation of coronary effects of atrial natriuretic peptide and the renin-angiotensin system in the isolated perfused rat heart. F Mol Cell Cardiol 1994;26:527-37. 